\title{
Identifikasi Fisikokimia dan Analisis Finansial Cookies Tepung Kulit Tauge Kacang Hijau dan Tepung Tempe
}

\author{
${ }^{1)}$ Neilatul Nuriyah, ${ }^{2)} \mathrm{M}$ Fuad Fauzul Mu'tamar, ${ }^{3)}$ Asfan \\ ${ }^{1,2,3)}$ Agroindustrial Technology Department, Universitas Trunojoyo Madura \\ 1)140331100042@student.trunojoyo.ac.id, 2)mfuadfm@gmail.com, 3)asfan@trunojoyo.ac.id
}

DOI: https://doi.org/10.21107/rekayasa.v12i2.5452

\begin{abstract}
ABSTRAK
Cookies atau biasa masyarakat Indonesia menyebutnya kue kering merupakan salah satu makanan ringan. Tepung kulit tauge kacang hijau dan tepung tempe dapat dimanfaatkan sebagai bahan pembuatan cookies. Penelitian ini bertujuan untuk mengetahui karakteristik fisikokimia, dan kelayakan finansial produk cookies kombinasi bahan baku tepung kulit tauge kacang hijau dengan tepung tempe.Metode penelitian menggunakan Rancangan Acak Kelompok (RAK) 2 faktor proporsi tepungkulit tauge kacang hijau dan tepung tempe dengan level sebagai berikut A (20:70), B (40:50), C (60:30), D (80:10), E (70:20), F (50:40), G (30:60), H (10:80). Karakteristik fisik menunjukkan bahwa tingkat kekerasan (hardness) berkisar dari 1,61-3,90 gf.. Karakteristik kimiawi cookies tepung kulit tauge dan tepung tempe menunjukkan bahwa kadar air berkisar 2,63-5,83, kadar protein berkisar 2,84-6,07 \% dan kadar serat berkisar 34,93-75,68\%. Proporsi tepung kulit tauge dan tepung tempe berpengaruh nyata $(p<0,05)$ terhadap hardness, rasa, warna, tekstur, aroma dan kesukaan keseluruhan. Hasil analisis financial usaha cookies tepung kulit tauge dan tepung tempe didapatkan nilai BEP Rp 10.797, nilai NPVRp 186.645.349, payback periode 1 tahun 4 bulan bulan dan Net B/C 1,85.
\end{abstract}

Kata kunci: Cookies, tepung kulit tauge, tempe.

\section{Identification of Physicochemistry and Financial Analysis of Skin Flour Green Cookies and Tempe Flour}

\section{ABSTRACT}

Cookies is one of a snack product. Mung bean husk flour and soybean cake flour can be used as the ingredient in making cookies. This study aims to determine the physico-chemical characteristics, and feasibility studies of a cookies. The research method used in this study was a Randomized Group Design (RGD) with 2 factors: the proportion of mung bean husk flour and soybean cake flour by the following levels: A (20:70), B (40:50), C (60:30), D (80:10), E (70:20), F (50:40), G (30:60), H (10:80). The physical characteristics showed that the hardness level of the cookies ranges from 1,61-3,90 gf. The chemical characteristics of the mung bean husk flour and soybean cake flour cookies showed that the moisture content was range $2,63-5,83 \%$, the protein content is in range $2,84-6,07 \%$, and the fiber content is in range $34,93-75,68 \%$. The proportion of mung bean husk flour and soybean cake flour significantly influenced $(p<0,05)$ the hardness level, taste, color, texture, smells and the overall contentment of the cookies. The results of the financial feasibility test showed that BEP was Rp 10.797, positive NPV (Rp 186.645.349), faster payback period (16 months), and Net $\mathrm{B} / \mathrm{C}$ value was 1.85 which suggests (Net B/C $>1$.

Keywords: cookies, soybean flour, tempe.

\section{PENDAHULUAN}

Cookies merupakan salah satu makanan ringan. Cookies memiliki tekstur renyah dan tidak mudah patah, sehingga dari kalangan anak-anak hingga dewasa menyukainya. Terdapat banyak macam cookies mulai dari cookies coklat, kelapa, sampai jajanan dan aneka toping penambahannya. Menurut (Sholikhan dan Nisa 2015), rata-rata masyarakat Indonesia mengkonsumsi 10 gram serat setiap harinya, sedangkan saran yang dianjurkan yaitu mengkonsumsi serat 30 gram setiap harinya. Asupan serat dari bahan pangan yang dikonsum-

\section{Article History:}

Received: Juni, 23th 2019; Accepted: September, 29th 2019 ISSN: 2502-5325 (Online) Terakreditasi Peringkat 3 oleh Kementerian Riset, Teknologi dan Pendidikan Tinggi (ARJUNA), berdasarkan Keputusan Direktur Jenderal Penguatan Riset dan Pengembangan No: 23/E/KPT/2019 tanggal 8 Agustus 2019 si kurang. Masyarakat Indonesia mengkonsumsi cookies 0,40 kg/kapita/tahun (Istiana 2013), dan sebagian besar bahan dasar dari terigu (Wisti 2011). Kandungan didalam terigu mengandung gluten, salah satu bahan lokal yang tidak mengandung glutten limbah kecambah yaitu kulit tauge dan tempe. Kulit tauge akan dijadikan tepung terlebih dahulu, untuk pengolahannya serta kandungan tepung kulit tauge dan tepung tempe akan memperkaya nilai gizi cookies.

Tempe merupakan makanan tradisional Indonesia terbuat dari kedelai. beberapa penelitian telah

\section{Cite this as:}

Nuriyah, N., Mu'tamar, M.F.F., dan Asfan, A.(2019). Identifikasi Fisikokimia dan Analisis Finansial Cookies Tepung Kulit Tauge Kacang Hijau dan Tepung Tempe. Rekayasa, 12(2), 98-103. doi: https://doi.org/10.21107/rekayasa.v12i2.5452

(C) 2019 Neilatul Nuriyah, M Fuad Fauzul Mu'tamar, Asfan 
memanfaatkan tempe dalam bentuk tepung untuk pembuatan aneka kue, kurniawati (2012) menambahkan tepung tempe dalam pembuatan roti manis. Selain itu penelitian santiko (2008) menunjukkan bahwa penambahan tepung tempe dapat meningkatkan penerimaan produk kue kering. Oleh karena itu dalam penelitian ini dicobakan penambahan tepung tempe dalam pembuatan cookies.

Penelitian dilakukan untuk mengetahui pengaruh perbandingan tepung tauge dan tepung tempe terhadap karakteristik fisikokimia dan analisis finansial produk cookies yang dihasilkan.

\section{BAHAN DAN METODE}

\section{Bahan}

Bahan utama adalah tepung tauge dan tepung tempe, bahan pendamping yaitu gula halus, margarin, kuning telur, dan susu bubuk. Bahan untuk uji kimia kadar protein dan serat yaitu $\mathrm{H}_{2} \mathrm{SO}_{4}$ $\mathrm{NaOH}$, aquades, alcohol, $\mathrm{CuSO}_{4^{\prime}} \mathrm{HCl}$, metal merah.

\section{Alat}

Alat yang digunakan untuk pembuatan produk penelitian yaitu, tampah, baskom, pisau, talenan, wajan, kompor, thermometer, loyang, cabinet dryer, grinder, timbangan, mixer, oven, texture analyzer. Sedangkan untuk uji kimia, kertas saring, autoclaf, cawan, desikator, timbangan, labu kjeldahl, lemari asam, Erlenmeyer, b uret.

Penelitian ini dilakukan pada bulan Oktober - Desember bertempat di Lab Analisis Mutu, dan Lab Rekayasa Proses Dan Bioindustri - Teknologi Industri Pertanian, Fakultas Pertanian, Universitas Trunojoyo Madura. Penelitian ini mengacu pada penelitian Istiana (2013), yang menambahkan tepung tempe dengan perbandingan 1:20 pada masing-masing sampel untuk jumlah keseluruhan bahan utama. Peneliti melakukan penelitian pendahuluan menggunakan konsentrasi dari 2070gram, 40-50 gram, 60-30 gram, dan 80-10 gram.

Desain penelitian menggunakan rancangan acak kelompok (RAK) 2 faktor dengan 3 kali pengulangan. Faktor pertama tepung kulit tauge dan faktor kedua tepung tempe dengan penambahan bahan tambahan proporsi sama setiap sampel proporsi tepung kulit tauge dan tepung tempe sebagai berikut:

$\mathrm{A}=10 \mathrm{~g}$ TKT:80g Tepung tempe

$\mathrm{B}=20 \mathrm{~g}$ TKT:70g Tepung tempe

$C=30 \mathrm{~g}$ TKT:60g Tepung tempe

$\mathrm{D}=40 \mathrm{~g}$ TKT:50g Tepung tempe

$\mathrm{E}=50 \mathrm{~g}$ TKT:40g Tepung tempe

$\mathrm{F}=60 \mathrm{~g}$ TKT:30g Tepung tempe

$\mathrm{G}=70 \mathrm{~g}$ TKT:20g Tepung tempe

$\mathrm{H}=10 \mathrm{~g}$ TKT:80g Tepung tempe
Perlakuan pengelompokan dilakukan karena bahan utama pembuatan tempe adalah kedelai. Kedelai oleh produsen tempe penggunaannya dari berbagai macam merek kedelai. Kemudian pada pengambilan bahan baku tepung kulit tauge dilakukan pengambilan bahan baku setiap 1 minggu sekali. Kulit tauge yang telah didapatkan dibersihkan dari kotoran menggunakan air mengalir, kemudian diblancing dengan suhu $90^{\circ} \mathrm{C}$ selama 5 menit, pengeringan suhu $50^{\circ} \mathrm{C}$ selama 6 jam.kemudian digrinder dan diayak menggunakan ayakan 100 mesh. Sedangkan tepung tempe dibuat dengan cara memotong tempe dengan ketebalan 0,5-1 cm. kemudian diblansing dengan suhu $90^{\circ} \mathrm{C}$ selama 15 menit, lalu dikeringkan dengan suhu $70^{\circ} \mathrm{C}$ selama 7 jam dan di grinder serta diayak menggunakan mesh 60. Kemudian akan dilakukan uji fisik hardness dan tekstur menggunakan alat tekstur analyzer. Uji selanjutnya yaitu uji kimia meliputi kadar air, serat dan protein serta uji analisis kelayakan financial.

\section{HASIL DAN PEMBAHASAN}

\section{Analisis Fisik Cookies Tepung Kulit Tauge Dan Tepung Tempe}

\section{Tingkat kekerasan (hardness)}

Hardness (kekerasan) merupakan kemampuan suatu benda dalam menahan beban jika terjadi penekanan. Ketika suatu benda diberikan gaya, maka struktur benda tidak bisa kembali pada bentuk awalnya. Pengujian tingkat kekerasan menggunakan texture analyzer menunjukkan bahwa proporsi tepung kulit tauge dan tepung tempe berpengaruh nyata $(p<0,05)$ terhadap kekerasan cookies.

Hasil pengujian menunjukkan rata-rata nilai tekstur hardness cookies tepung kulit tauge dan

Tabel 1. Rata-Rata Nilai Tekstur Hardness Cookies Tepung Kulit Tauge dan Tepung Tempe

\begin{tabular}{cc}
\hline $\begin{array}{c}\text { Proporsi Tepung Kulit } \\
\text { Tauge : Tepung Tempe } \\
(\mathbf{g})\end{array}$ & Rata-Rata (g) \\
\hline $20: 70$ & $3,764 \times 10^{3 \mathrm{~b}}$ \\
$40: 50$ & $4,1478 \times 10^{3 \mathrm{bc}}$ \\
$60: 30$ & $4,9016 \times 10^{3 \mathrm{abc}}$ \\
$80: 10$ & $5,2328 \times 10^{3 \mathrm{~cd}}$ \\
$70: 20$ & $5,8928 \times 10^{3 \mathrm{~d}}$ \\
$50: 40$ & $4,098 \times 10^{3 \mathrm{bc}}$ \\
$30: 60$ & $4,5619 \times 10^{2 \mathrm{a}}$ \\
$10: 80$ & $1,6848 \times 10^{3 \mathrm{a}}$ \\
\hline
\end{tabular}

Keterangan : Angka yang diikuti dengan huruf berbeda menunjukkan beda nyata berdasarkan uji jenis duncan $5 \%$. 
100 | Nuriyah, N. dkk., Identifikasi Fisikokimia dan Analisis Finansial Cookies...

tepung tempe. Proporsi tertinggi pada tepung kulit tauge 70 gram dengan nilai 5,8928 $\times 10^{3}$. Nilai terendah pada tepung kulit tauge 30 gram dengan nilai 4,5619 $\times 10^{2}$. Cookies dengan penambahan tepung kulit tauge akan keras teksturnya. mengatakan bahwa cookies dengan campuran tepung kulit tauge semakin banyak akan menghasilkan cookies bertekstur keras. Semakin banyak tepung tempe yang ditambahkan akan mempengaruhi tekstur cookies yang semakin renyah. Hal ini sesuai dengan (Handayani 2009), mengatakan bahwa cookies dengan campuran tepung kulit tauge, semakin banyak akan menghasilkan cookies bertekstur keras. Semakin banyak tepung tempe yang ditambahkan akan mempengaruhi tekstur cookies yang semakin renyah. Penambahan tepung tempe mempengaruhi tingkat kelembutan cookies (Maulina 2015).

\section{Analisis Kimia Cookies Tepung Kulit Tauge Dan Tepung Tempe}

\section{Analisis Kadar Air}

Hasil pengujian kadar air menunjukkan bahwa formulasi tepung kulit tauge dan tepung tempe pada cookies tidak berpengaruh pada kadar air dengan nilai signifikansi 0,733 ( $p>0,05)$.

Nilai rata-rata kadar air keseluruhan sampel menunjukkan tidak ada perbedaan nyata secara statistik. Nilai tertinggi pada proporsi tepung kulit tauge 40 gram.Nilai terendah pada proporsi tepung kulit tauge $20 \mathrm{gram}$. Tepung tempe memiliki kandungan karbohidrat yang didalamnya mengandung pati. Susunan dari kandungan pati yaitu amilosa dan amilopektin. Amilopektin memiliki sifat sukar menyerap air dan sukar menyerap air (Harzau dan Teti 2013).

\section{Analisis Kadar Protein}

Uji kadar protein dilakukan pada 8 sampel ditun-

Tabel 2. Rara-Rata Nilai Kadar Air Cookies Tepung Kulit Tauge dan Tepung Tempe

\begin{tabular}{cc}
\hline $\begin{array}{c}\text { Proporsi Tepung Kulit Tauge : } \\
\text { Tepung Tempe (g) }\end{array}$ & Rata-Rata \\
\hline $20: 70$ & $2,6333 \mathrm{a}$ \\
$40: 50$ & $5,8333 \mathrm{a}$ \\
$60: 30$ & $5,2667 \mathrm{a}$ \\
$80: 10$ & $5,4333 \mathrm{a}$ \\
$70: 20$ & $4,3333 \mathrm{a}$ \\
$50: 40$ & $3,9333 \mathrm{a}$ \\
$30: 60$ & $5,1667 \mathrm{a}$ \\
$10: 80$ & $4,6667 \mathrm{a}$ \\
\hline
\end{tabular}

Keterangan : Angka yang diikuti dengan huruf berbeda menunjukkan beda nyata berdasarkan uji jenis duncan $5 \%$. jukkan pada Tabel 3. Kadar protein tertinggi pada proporsi tepung kulit tauge dan tepung tempe perbandingan 40:50 dan 50:40. Menurut Maulina (2015) kadar protein menurun dikarenakan terjadi proses pengovenan. Pendapat yang sama menurut Warsito et.al (2015) mengatakan bahwa terjadi denaturasi protein karena suhu panas. Sebelum proses pembuatan tepung tempe terdapat perlakuan blanching yang menyebabkan penurunan kadar protein. Proses tesebut akan melepas ikatan struktur protein dan mengakibatkan komponen protein terlarut dalam air (Midayanto dan Yuwono 2014). Proses pengovenan akan menurunkan nilai gizi pada cerealia. Kerusakan dikarenakan pemanasan akan mengurangi tersedianya asam amino essensial lisin akibat terjadinya denaturasi protein. Pendapat lain mengatakan faktor yang mempengaruhi penurunan kadar protein yaitu penambahan bahan, pengukusan, dan lama fermentasi. Turunnya kadar protein tempe karena Rizopus sp mendenaturasi tempe. Kapang yang berada didalam tempe akan menghidrolisis senyawa kompleks sehingga menjadi senyawa yang mudah dicerna (Drajat et.al 2014). Kandungan protein cookies tertinggi melebihi batas yang ditentukan oleh SNI kue

Tabel 3. Rata-rata Nilai Kadar Protein Cookies Tepung Kulit Tauge dan Tepung Tempe

\begin{tabular}{cc}
\hline $\begin{array}{c}\text { Proporsi Tepung Kulit } \\
\text { Tauge : Tepung Tempe } \\
(\mathbf{g})\end{array}$ & Kadar Protein (\%) \\
\hline $20: 70$ & 5,5051 \\
$40: 50$ & 6,0654 \\
$60: 30$ & 4,6646 \\
$80: 10$ & 2,8436 \\
$70: 20$ & 4,1043 \\
$50: 40$ & 6,0654 \\
$30: 60$ & 3,1237 \\
$10: 80$ & 4,6646 \\
\hline
\end{tabular}

Tabel 4. Rara-Rata Nilai Kadar Serat Cookies Tepung Kulit Tauge dan Tepung Tempe

\begin{tabular}{cc}
\hline $\begin{array}{c}\text { Proporsi Tepung Kulit Tauge : } \\
\text { Tepung Tempe (g) }\end{array}$ & Rata-Rata (\%) \\
\hline $20: 70$ & $34,9333^{\mathrm{a}}$ \\
$40: 50$ & $51,2500^{\mathrm{abc}}$ \\
$60: 30$ & $75,6833^{\mathrm{c}}$ \\
$80: 10$ & $65,0667^{\mathrm{bc}}$ \\
$70: 20$ & $53,7917 \mathrm{abc}$ \\
$50: 40$ & $65,0417^{\mathrm{bc}}$ \\
$30: 60$ & $42,6250^{\mathrm{ab}}$ \\
$10: 80$ & $45,8700^{\mathrm{ab}}$ \\
\hline
\end{tabular}

Keterangan : Angka yang diikuti dengan huruf berbeda menunjukkan beda nyata berdasarkan uji jenis duncan $5 \%$. 
kering (cookies) dengan batasan maksimum 6\%. Artinya cookies dapat memenuhi standart yang ditentukan. Cookies proporsi lainnya masih berada dibawah SNI kue kering dari 2,8436-4,6646\%. Kadar protein didapat dari tepung tempe sebanyak 43,15965\% (Maulina 2015).

\section{Analisis Kadar Serat}

Pengujian kadar serat memberikan gambaran terjadi pengaruh signifikan dengan nilai signifikansi $0,018(\mathrm{p} 0,05)$ terhadap kadar serat, akibat proporsi tepung kulit tauge dan tepung tempe.

Tabel 4. menunjukkan Nilai rata-rata proporsi tepung kulit tauge 30 gram dan 10 gram tidak berbeda nyata. Tepung kulit tauge proporsi 40 gram dan 70 gram tidak mengalami perbedaan nyata. Tepung kulit tauge 80 gram dan 50 gram juga tidak berpengaruh nyata. Sampel tepung kulit tauge 20 gram, 60 gram berbeda nyata terhadap kadar serat cookies. Kadar serat terbanyak pada proporsi tepung kuli tauge dan tepung tempe 60:30. Diduga kandungan serat terbanyak pada tepung kulit tauge dengan penambahaan kadar serat tepung tempe. Kandungan serat tepung tempe 18,496\% (Maulina 2015). Cookies tepung kulit tauge dan tepung tempe memiliki kadar serat lebih besar dari SNI kue kering yaitu maksisum 5,0. Sehingga cookies sangat baik untuk kandungan seratnya.

\section{Analisis Uji Sensoris Cookies Tepung Kulit Tauge Dan Tepung Tempe}

\section{Rasa}

Daya terima konsumen sangatlah penting dalam hal rasa. Rasa salah satu faktor penentuan mutu produk dan menjadi atribut penting. Rasa berasal dari komposisi produk tersebut dan proses pemasakannya (Mayasari 2015). hasil anova menun- $P$ jukkan bahwa nilai signifikansi hasil uji sensoris parameter rasa cookies tepung kulit tauge dan tepung tempe berpengaruh nyata $(p<0,05)$ terhadap rasa.

Semakin banyak proporsi tepung tauge maka rasa cookies akan semakin enak. Semakin tinggi proporsi tepung kulit tauge maka semakin disukai oleh panelis. Cookies proporsi tepung tauge semakin banyak menurut panelis seperti rasa coklat. Penambahan tepung kulit tauge dalam jumlah banyak mempengaruhi rasa cookies. Ketika seluruh adonan dicampurkan aroma seperti coklat. Penambahan tepung tempe menjadikan cookies terasa asam dan tidak disukai oleh panelis. Panelis menganggap cookies proporsi tepung tempe terbanyak rasanya asam.
Tabel 5. Rara-Rata Nilai Uji Rasa Cookies Tepung Kulit Tauge dan Tepung Tempe

\begin{tabular}{cc}
\hline $\begin{array}{c}\text { Proporsi Tepung Kulit } \\
\text { Tauge : Tepung Tempe }(\mathrm{g})\end{array}$ & Rata-Rata \\
\hline $20: 70$ & $1,62^{\mathrm{a}}$ \\
$40: 50$ & $2,06^{\mathrm{bc}}$ \\
$60: 30$ & $2,74^{\mathrm{d}}$ \\
$80: 10$ & $3,09^{\mathrm{e}}$ \\
$70: 20$ & $2,62^{\mathrm{d}}$ \\
$50: 40$ & $2,11^{\mathrm{c}}$ \\
$30: 60$ & $1,83^{\mathrm{ab}}$ \\
$10: 80$ & $1,61^{\mathrm{a}}$ \\
\hline
\end{tabular}

Keterangan : Angka yang diikuti dengan huruf berbeda menunjukkan beda nyata berdasarkan uji jenis duncan $5 \%$.

Tabel 6. Rara-Rata Nilai Warna Cookies Tepung Kulit Tauge dan Tepung Tempe

\begin{tabular}{cc}
\hline $\begin{array}{c}\text { Proporsi Tepung Kulit } \\
\text { Tauge : Tepung Tempe }(g)\end{array}$ & Rata-Rata \\
\hline $20: 70$ & $1,47^{\mathrm{a}}$ \\
$40: 50$ & $2,53^{\mathrm{c}}$ \\
$60: 30$ & $3,28^{\mathrm{d}}$ \\
$80: 10$ & $3,90^{\mathrm{f}}$ \\
$70: 20$ & $3,58^{\mathrm{e}}$ \\
$50: 40$ & $2,64^{\mathrm{c}}$ \\
$30: 60$ & $1,78^{\mathrm{b}}$ \\
$10: 80$ & $1,64^{\mathrm{ab}}$ \\
\hline
\end{tabular}

Keterangan : Angka yang diikuti dengan huruf berbeda menunjukkan beda nyata berdasarkan uji jenis duncan $5 \%$.

\section{Warna}

Pengujian organoleptic menunjukkan bahwa proporsi tepung kulit tauge dan tepung tempe berdampak nyata $(p<0,05)$ terhadap warna. Proporsi tepung kulit tauge berpengaruh terhadap kecerahan warna.

Semakin banyak proporsi tepung tauge maka warna cookies akan menjadi lebih gelap. Cookies yang memiliki perbedaan nyata dikarenakan perbedaan proporsi tepung kulit tauge dan tepung tempe. Perbedaan warna cookies disebabkan karena bahan yang dipakai berbeda pula. Faktor yang mempengaruhi perubahan warna cookies karena adanya penambahan tepung kulit tauge. Tepung kulit tauge yang berwarna hijau tua dan kulit tauge mengandung klorofil. Ketika klorofil terkena proses pemanasan warna kulit tauge berubah menjadi lebih pekat. Proses blansing menyebabkan kulit tauge dari warna hijau menjadi berwarna hijau tua kecoklatan. 
102 | Nuriyah, N. dkk., Identifikasi Fisikokimia dan Analisis Finansial Cookies...

\section{Aroma}

Hasil organoleptic menunjukkan bahwa proporsi tepung kulit tauge dan tepung tempe berpengaruh nyata $(p<0,05)$ terhadap aroma cookies yang dihasilkan.

Aroma yang tidak disukai yaitu pada proporsi 60 gram sedangkan aroma cookies yang disukai pada tepung tauge $30 \mathrm{gram}$. Aroma khas tepung tempe lebih disukai oleh panelis dengan proporsi tepung kulit tauge 30 gram dan tepung tempe 60 gram. Bau khas cookies disebabkan komponen bahan cookies tersebut dengan penambahan gula dan margarine. Serta proporsi dari kedua tepung dan proses pemanggangan merupakan faktor aroma cookies.

\section{Kesukaan Keseluruhan}

Parameter kesukaan keseluruhan cookies menunjukkan bahwa proporsi tepung tauge dan tepung tempe berpengaruh nyata $(p<0,05)$. Panelis menganggap bahwasannya dari keseluruhan parameter rasa, warna, aroma, tekstur berpengaruh nyata pada kesukaan keseluruhan cookies tepung kulit tauge dan tepung tempe.

Proporsi tepung tauge tidak berbeda nyata pada sampel 60 gram, 80 gram, 70 gram. Sehingga ketiga proporsi tersebut memiliki nilai tertinggi. Panelis menganggap ketiga proporsi tersebut memiliki kesukaan keseluruhan sama. Sampel yang tidak berbeda nyata pada tepung tauge 20 gram, 40

Tabel 7. Rara-Rata Nilai Aroma Cookies Tepung Kulit Tauge dan Tepung Tempe

\begin{tabular}{cc}
\hline $\begin{array}{c}\text { Proporsi Tepung Kulit Tauge : } \\
\text { Tepung Tempe (g) }\end{array}$ & Rata-Rata \\
\hline $20: 70$ & $1,93^{\mathrm{c}}$ \\
$40: 50$ & $1,73^{\mathrm{bc}}$ \\
$60: 30$ & $1,40^{\mathrm{a}}$ \\
$80: 10$ & $1,51^{\mathrm{ab}}$ \\
$70: 20$ & $1,50^{\mathrm{ab}}$ \\
$50: 40$ & $1,78^{\mathrm{c}}$ \\
$30: 60$ & $1,98^{\mathrm{c}}$ \\
$10: 80$ & $1,86^{\mathrm{c}}$ \\
\hline
\end{tabular}

Keterangan : Angka yang diikuti dengan huruf berbeda menunjukkan beda nyata berdasarkan uji jenis duncan $5 \%$. gram, 50 gram, 30 gram, dan 10 gram. Nilai cookies terendah pada tepung tauge 20 gram. Karena cookies memiliki rasa tepung kulit tauge dominan dan tepung tempe sebagai penyeimbang rasa. Panelis menganggap dari segi kesukaan keseluruhan terbaik pada cookies sampel perbandingan 60:30 gram, 80:10 gram dan 70:20 gram.

\section{Analisis Finasial}

Hasil analisis finansial cookies yang di hasilkan ditunjukkan pada Tabel 9.

Hasil analisis dapat dinyatakan usaha industri dalam bidang cookies tepung kulit tauge dan tepung tempe layak dijalankan. Hasi nilai BEP Rp 10.797 dengan produksi cookies 1000 toples. Nilai NPV yang positif Rp 186.645.349 selama periode operasi 2 tahun dan payback periode lebih cepat yaitu 1 tahun 4 bulan bulan umur investasi. Net $B / C$ lebih besar dari satu (Net $B / C>1$ ) yaitu 1,85 sehingga usaha dapat dijalankan. usaha produksi cookies tepung kulit tauge dan tepung tempe layak untuk dijalankan. Apabila dilakukan efisiensi usaha dan peningktan harga jual. Nilai NPV dan payback periods tersebut akan menjadi lebih baik pula. Jika promosi dilakukan dan berjalan dengan baik, maka nilai NPV, dan payback periode menjadi lebih baik.

\section{KESIMPULAN}

Hasil penelitian dan pembahasan penelitian

Tabel 8. Rara-Rata Nilai Tingkat Kesukaan Keseluruhan Cookies Tepung Kulit Tauge dan Tepung Tempe

\begin{tabular}{cc}
\hline $\begin{array}{c}\text { Proporsi Tepung Kulit Tauge : } \\
\text { Tepung Tempe (g) }\end{array}$ & Rata-Rata \\
\hline $20: 70$ & $1,99^{\mathrm{a}}$ \\
$40: 50$ & $2,33^{\mathrm{bc}}$ \\
$60: 30$ & $3,62^{\mathrm{e}}$ \\
$80: 10$ & $3,56^{\mathrm{e}}$ \\
$70: 20$ & $3,31^{\mathrm{e}}$ \\
$50: 40$ & $2,67^{\mathrm{d}}$ \\
$30: 60$ & $2,39^{\mathrm{cd}}$ \\
$10: 80$ & $2,03^{\mathrm{ab}}$ \\
\hline
\end{tabular}

Keterangan : Angka yang diikuti dengan huruf berbeda menunjukkan beda nyata berdasarkan uji jenis duncan $5 \%$.

Tabel 9. Analisis Finansial Industri Cookies Tepung Kulit Tauge dan Tepung Tempe

\begin{tabular}{cccc}
\hline Analisis Kelayakan Usaha & Hasil Pengukuran & Keterangan & Layak \\
\hline NPV (12\%) & Rp. 186.645.349 & Layak & Positif \\
Net B/C & 1,85 & Layak & (Net B/C >1) \\
Pp & 1 Tahun 4 Bulan & Layak & $\leq$ Umur Investasi \\
BEP: Rupiah & Rp. 10.797.Toples & Layak & $\neq 0$ \\
\hline
\end{tabular}


mengenai cookies tepung kulit tauge dan tepung tempe dapat disimpulkan sebagai berikut :

1. Karakteristik fisik menunjukkan bahwa tingkat kekerasan (hardness) berkisar dari 1,61-3,90. Tingkat kekerasan terendah1,61 pada proporsi tepung kulit tauge dan tepung tempe (10:80) dan tertinggi 3,09 proporsi (80:10).

2. Karakteristik kimiawi cookies tepung kulit tauge dan tepung tempe menunjukkan bahwa kadar air berkisar 2,633-5,833\% melebihi SNI maksimum 5\%., kadar protein berkisar 2,8436$6,0654 \%$ melebihi maksimum SNI 6\% dan kadar serat berkisar dari 34,9333-75,6833\% melebihi SNI maksimum 0,5\%.

3. Proporsi tepung kulit tauge dan tepung tempe berpengaruh nyata $(p<0,05)$ terhadap hardness, rasa, warna, tekstur, aroma dan kesukaan keseluruhan.

4. Hasil analisis finansial usaha cookies tepung kulit tauge dan tepung tempe didapatkan nilai BEP Rp 10.797, nilai NPV Rp 186.645.349, payback periode yaitu 1 tahun 4 bulan bulan umur investasi dan Net $B / C$ 1,85

\section{DAFTAR PUSTAKA}

Drajat D. P., Wahono H. S., Indria P. 2014. Pengaruh Umur Fermentasi Temped An Proporsi Dekstrin Terhadap Kualitas Susu Tempe Bubuk. Jurnal Pangan Dan Agroindustri. 2 (1) : 4753.

Kurniawati, Ayustaningwarno F., 2012, pengaruh subtitusi tepung terigu dengan tepung temped an tepung ubi jalar kuning terhadap kadar protein, kadar $\beta$ karoten dan mutu organoleptic roti manis. Jurnal of nutrition collage, 1(1):344-351
Maulina A. 2015. Eksperimen Pembuatan Cake Subtitusi Tepung Tempe. [Skripsi]. Jurusan Pendidikan Kesejahteraan Keluarga. Fakultas Teknik. Universitas Negeri Semarang.

Mayasari R. 2015. Kajian Karakteristik Biskuit yang dipengaruhi Perbandingan Tepung Ubi Jalar (Ipoema Batatas L.) dan Tepung Kacang Merah (Phaseolus Vulgaris L.). Program Studi Teknologi Pangan. Fakultas Teknik. Universitas Pasundan Bandung.

Midyanto D. N., Sudarminto S.Y. 2014. Penentuan Atribut Mutu Tekstur Tahu Untuk Direkomendasikan Sebagai Syarat Tambahan Dalam Standart Nasional Indonesia. Jurnal Pangan Dan Agroindustri. 2 (4) : 259-267.

Sholikhah F. S., Fithri C. N. 2015. Cookies Beras Pratanak (Kajian Proporsi Tepung Beras Pratanak Dengan Tepung Terigu Dan Penambahan Shortening). Jurnal Pangan Dan Agroindustri. 3 (3) : 1180-1191.

Utiarahman G., Rita M. H., Nikmawatisusanti Y. 2013. Karakteristik Kimia Dan Organoleptik Nugget Ikan Layang (Decapterus Sp.) Yang Disubtitusi Tepung Ubi Jalar Putih (Ipoema Batatas L.) Jurnal Ilmiah Perikanan Dan Kelautan. 1 (3) : 126-138.

Warsito H., Rindiani., Fafa N.2015. Ilmu Bahan Makanan Dasar. Yogyakarta : Nuha Medika.

Wisti C. 2011. Pembuatan Kue Kering Dengan Tepung Ubi Jalar Unggu (Ipoema Batatas Poier). [Tugas Akhir] Program Studi Teknologi Jasa Dan Produksi. Fakultas Teknik. Universitas Negeri Semarang. 